Original Research Paper

\title{
Assessment of Geothermal Energy Potential of Ruwan Zafi, Adamawa State and Environs, Northeastern Nigeria, using High Resolution Airborne Magnetic Data
}

\author{
${ }^{1}$ Ibe Stephen Onyejiuwaka and ${ }^{2}$ Uche Kelvin Iduma \\ ${ }^{1}$ Federal University Otuoke, Bayelsa, Nigeria \\ ${ }^{2}$ Nigerian Geological Survey Agency, Abuja, Nigeria
}

Article history

Received: 10-05-2020

Revised: 27-11-2020

Accepted: 04-12-2020

Corresponding Author:

Ibe Stephen Onyejiuwaka

Federal University Otuoke,

Bayelsa, Nigeria

Email: stphnibe@yahoo.com

\begin{abstract}
The aeromagnetic dataset over Ruwan Zafi, Adamawa State and environs, Northeastern Nigeria, was interpreted in this study, in order to map out places with the potentials for application of geothermal energy for electricity generation and geothermal direct heating. The analysis of the spectral of the magnetic dataset delineated the range of the sediment thickness as 4273.58 and $8693.32 \mathrm{~m}$ and top boundary to magnetic bodies estimated at depths ranging from 89.62 to $235.38 \mathrm{~m}$, within the study area. The range of the estimated basal depth is between 8.40 and $17.16 \mathrm{~km}$; the geothermal gradient range is between 33.79 and $69.01{ }^{\circ} \mathrm{C} / \mathrm{km}$ and the associated mantle heat flow varies from about 84.48 to $172.53 \mathrm{~mW} / \mathrm{m}^{2}$. The results suggest that the geothermal prospect areas delineated in this study, are most likely the areas where thin layer of thermally insulated sediments cover the basement rocks and volcanic activities, or the places with the shallowest depth to magnetic sources, as observed in Lamurde, Ruwan Zafi, Lafia, Kiri, Banjiran and Shellen Areas. Also, the geothermal gradient greater than $48.11^{\circ} \mathrm{C} / \mathrm{km}$ and heat flow greater than $120.26 \mathrm{~mW} / \mathrm{m}^{2}$ in these areas reflect high potentials of the occurrences of geothermal resources in those places.
\end{abstract}

Keywords: Ruwan Zafi Area, Basal Depth, Geothermal Gradient, Heat Flow, Geothermal Prospect

\section{Introduction}

Power generation and distribution is one of the major key indicators of economic prosperity for a country. It is absolutely essential, crucial and unavoidably necessary for a country's development and human existence. For a country to effectively meet her citizen's demand for energy, electricity must be produced with diverse energy sources and technologies. According to (USEIA, 2019), the country (USA) employs varieties of energy sources and technologies to generate and distribute electricity. Electricity generation is based on three major categories of energy, namely nuclear energy, fossil fuels and renewable energy sources. Most electricity is generated with steam turbines using fossil fuels, nuclear, biomass, geothermal and solar thermal energy. Other major electricity generation technologies include gas, hydro and wind turbines and solar photovoltaics.

In Nigeria the primary sources of energy for the production of electricity are water, oil, gas and coal; hence, the types of power plants in the country are the hydro-electric and the thermal/fossil fuel power plants. Hydroelectric power systems and gas-fired systems are the two main power generating systems used presently. With these sources of electric power generation, Nigeria has grossly not met her citizens' demand for electricity. About $60 \%$ of the country's population has no access to electricity services (Akuru and Okoro, 2014). Electricity consumption per capita in Nigeria is about $100 \mathrm{kWh}$ and this compares poorly with 4,500, 1934 and $1379 \mathrm{kWh}$ in South Africa, Brazil and China, respectively (Akuru and Okoro, 2014). This has resulted to very poor industrial growth and high unemployment rate in the country.

Fossil fuel resources are not renewable and their usages contribute greenhouse gases significantly to the atmosphere. The world is transiting from generation of electric energy with fossil fuel to renewable energy sources that are environmentally friendly. Newsom (2012) observed that Nigeria is richly endowed with renewable energy resources and if effectively utilised for 
the generation of electricity, could ameliorate its supply, especially, in the rural communities. In 2016 the international energy agency reported that in transiting away from fossil fuel, renewable energy sources constitute about nine-tenths of new power which Europe added to the continent's electricity grids in 2015 . America is known to be the world leader in electricity generation through geothermal sources and according to the 2018 state energy data, about 16 terawatt-hours of the total electricity energy supplied and consumed in the country is generated from geothermal sources.

Owing to increasing quest for energy, boasting electricity generation in Nigeria with renewable and alternative energy sources has become a necessity. It is imperative to utilize Nigerian's huge natural endowments to achieve this goal. One of the natural endowments that has not been utilized for large scale generation of electricity in Nigeria is geothermal resources. In this study the aeromagnetic data over Ruwan Zafi, Adamawa State and environs, northeastern Nigeria were interpreted to examine the structures underlying the areas, geared toward assessing their geothermal viability. However, Nigerian government has not utilized the findings and recommendations previously made by researchers on geothermal energy, for electricity generation in the country. This is most likely due to the great depths, associated with the heat sources that are sufficient to produce significant temperature for the generation of electric power at commercial scale, as estimated by those researchers. Unlike those studies, many locations within the study area are known for the occurrences of warm springs, denoting shallowness of the heat source(s) in the area. This insinuates the cost effectiveness, in exploiting the heat from the source(s), for the generation of electric power and geothermal direct heating. Additionally, the heat and geothermal gradients estimated in those previous studies were based on a standard for Curie point isotherm of $580^{\circ} \mathrm{C}$. There was no consideration for the average surface temperature (noise) of about $30^{\circ} \mathrm{C}$ in the estimations of heat and geothermal gradients. Since the temperature under study corresponds to the exploitable temperature at depth, $550^{\circ} \mathrm{C}$ would have been a better constant temperature for the estimation of geothermal gradients in Nigeria. This study considered the average surface temperature in the estimation of the depths to the heat sources.

Early research on geothermal gradient studies using spectral analysis of geomagnetic data covered Japan (Okubo and Matsunaga, 1994), United States of America (Mayhew, 1985; Blakely, 1988) and Greece (Tsokas et al., 1998; Stampolidis and Tsokas, 2002); they all made successes in deriving the depth to geologic structures under investigation, such as magnetic basement. Tselentis (1991) had emphatically affirmed that the study of the changes in Curie isotherm depth of an area has afforded worthwhile facts about the regional temperature distribution at depth and the concentration of subsurface geothermal energy; the region with considerable geothermal energy is signalised by an anomalous high temperature gradient and heat flow. Hence, geothermally active areas are analogous with shallow Curie point depth (Dolmaz et al., 2005).

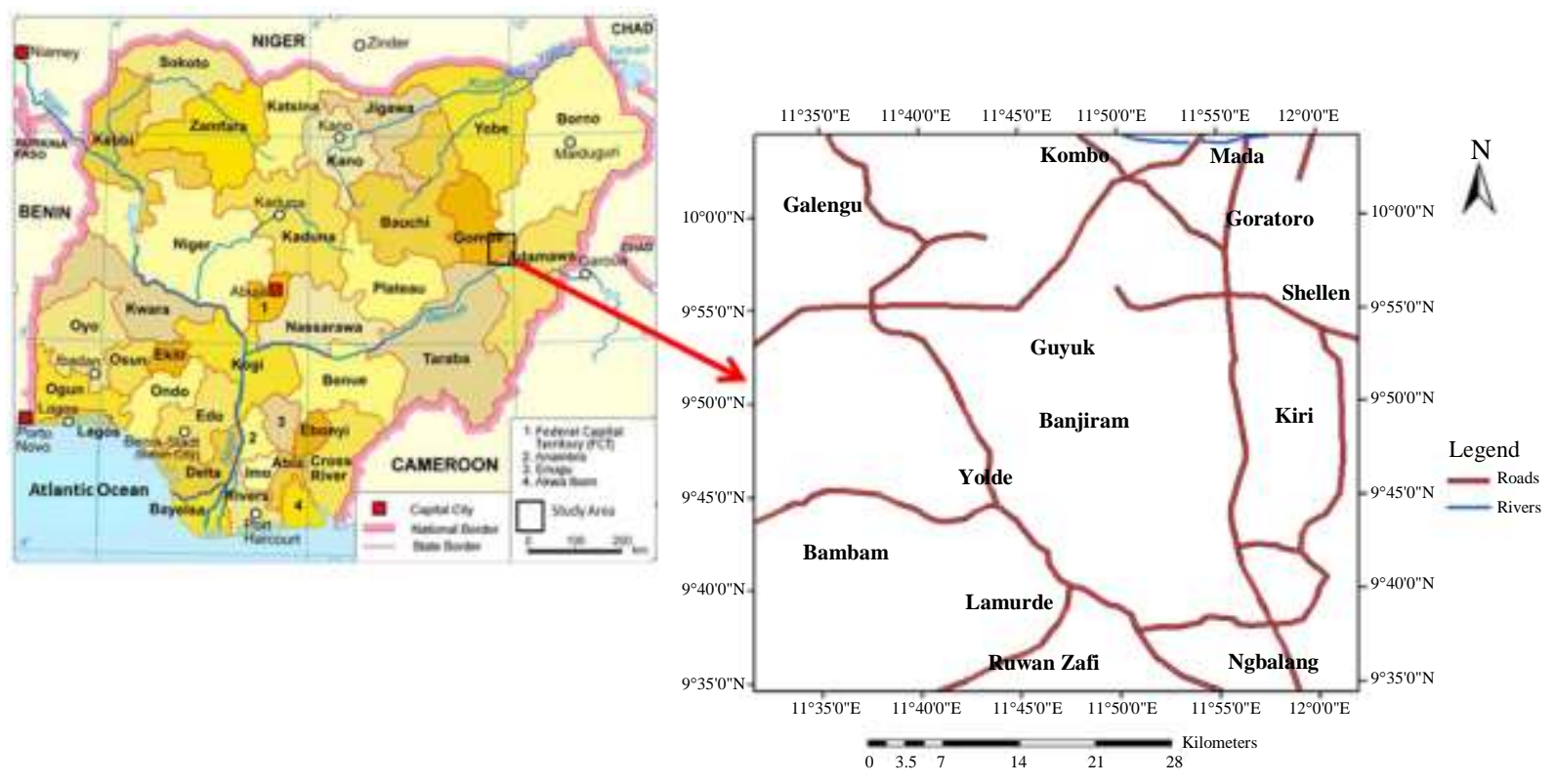

Fig. 1: Map of Nigeria and its environs (adopted from Charles and Omokenu, 2018) showing accessibility roads of the study area 


\section{Location and Geologic Settings of Study Area}

The area is bounded by longitudes $11^{\circ} 32^{\prime} 00^{\prime \prime} \mathrm{E}$ and $12^{\circ} 02^{\prime} 00^{\prime \prime} \mathrm{E}$ and latitudes $9^{\circ} 35^{\prime} 00^{\prime \prime} \mathrm{N}$ and $10^{\circ} 05^{\prime} 00^{\prime \prime} \mathrm{N}$ (Fig. 1) and the major towns within it include Ruwan Zafi, Lafia, Yolde, Banjiram, Galengu, Mada and Ngbalang. The area can be accessed through NumanYolde Road, Jagali-Goretoro Road, Kaltungo-Yolde Road and Goretoro-Numan Road.

Geologically, the study area falls within the contact between the Northern Benue Trough and North Eastern Basement Massif; it is located in the Gongola Basin. Sedimentation in the gongola basin began with the deposition of the continental Bima Sandstone in the Late Aptian - Early Abian (Abubakar et al., 2006), which unconformable overlies the Precambrian Basement Complex. The bima Sandstone, about $3500 \mathrm{~m}$ in thickness, was derived from the granitic Basement Complex and consists of feldspathic sandstones and clays which pass upwards into coarse to medium grained sandstones with less feldspar (Guiraud, 1990).

Conformably overlying the Bima Formation is about $200 \mathrm{~m}$ thick Yolde Formation, comprising variable sequence of shales and thin-bedded sandstones at the base and subsequently followed by alternations of sandy mudstones and shelly limestone. About $240 \mathrm{~m}$ thick dominant marine shale with limestone, known as Pindiga Formation, overlies the Yolde Formation. Pindiga Formation most likely was deposited under marine conditions that prevailed during the Early - Late Turonian and Coniacian times in the Northern Benue Trough and is overlain by Gombe Formation. Gombe Sandstone predominantly comprises clay and grits; lithologically, it comprises fine to very fine grained sandstone, siltstones, mudstones and shales and has attained a maximum thickness of about $320 \mathrm{~m}$.

A Formation of Paleocene age, comprising gently dipping continental conglomerates, clays, sandstones and siltstones and known as Kerri-Kerri Formation, is the youngest formation in the Gongola Basin. It oversteps the Gombe Formation onto older formations. Owing to the folded and faulted characteristics of Gombe Formation, the continental clastics of the Kerri Kerri Formation attains a thickness of about $320 \mathrm{~m}$, though variable thicknesses occurs in the eastern margin of the basin due to irregular tectonic features and small inliers.

\section{Materials, Methods and Data Processing}

The aeromagnetic dataset used for this study is from the high-resolution airborne magnetic survey coverage in Nigeria in 2009 carried out by Fugro Airborne Survey. The data, acquired from the Nigerian
Geological Survey Agency, were collected along a series of NW-SE flight lines at $500 \mathrm{~m}$ spacing, $20 \mathrm{~km}$ tie lines spacing and at $100 \mathrm{~m}$ terrain clearance. The parameter measured was the total magnetic field intensity. This study involved the data from one square block of aeromagnetic map (generated from Map Sheet 174), which was published on a scale of $1: 100,000$, covering approximately $3,025 \mathrm{~km}^{2}$. The total magnetic intensity grid was developed by employing a minimum curvature algorithm at $100 \mathrm{~m}$ grid cell size. The digitized data were filtered by utilising a low pass Fourier domain sub-routine filter to exterminate undesired wavelengths and to pass longer wavelengths. The aeromagnetic dataset was subjected to Reduction-To-Pole (RTP) transformation to reduce appreciably the polarity effects. A computer program, Geosoft (Oasis Montaj, version 8.4), was utilised to generate the residual magnetic anomaly values; this was achieved by subtracting regional fields values, from the measured intensity of the total field, at the grid cross point.

Fast Fourier Transform (FFT) is the mathematical device employed for the spectral analysis and applied to regularly spaced data, such as the dataset of the aeromagnetic field intensity, to work out and interpret the spectrum of the potential field. It accomplishes the transformation of magnetic dataset from space domain to frequency domain. Application of spectrum analysis technique to determine Curie point depth was carried out by separating the upshot of different bodies' parameters in the measured anomaly of the magnetic field (Hisarli, 1996). In this study, the FOURPOT software (Pirttijärvi, 2014), which is a potential field dataset processing and analysis of using 2-D Fourier transform, was used to generate the spectral plots. The depth to top boundaries to magnetic sources and the sediment thickness (centroid) were estimated from the spectra of the magnetic anomalies and these were utilised to compute the basal depths. Aimed at achieving increased resolution of the resultant depth values, the residual map of the area was split into nine overlapping blocks (Fig. 2) of spectral Cells of $18.3 \mathrm{~km}$ by $18.3 \mathrm{~km}$ each, so that longer wavelengths could be accommodated and maximum depth investigated.

The 2-D FFT technique was employed in the FOURPOT software (Pirttijärvi, 2014), in the transformation of the anomalous field dataset into the radial energy spectrum, for each spectral cell block. To execute this analysis, the computation of the average radial energy spectrum was accomplished and for each cell (Fig. 2), the graph of the natural logarithm of energy against frequency was plotted. From the spectral depth analysis, estimation of the depth to Centroid $\left(z_{0}\right)$ 
of the magnetic sources was accomplished from the slope of the low frequency component part of the energy spectrum and top boundary depth $\left(z_{t}\right)$ was estimated from the slope of the high frequency component part of the spectral segment. Computed $z_{0}$ and $z_{t}$ were used to estimate the basal depth $z_{b}$ by employing Equation 1 and this is considered as the Curie point depth (Kasidi and Nur, 2012):

$$
z_{b}=2_{z_{0}}-z_{t}
$$

Estimation of the heat flow and the geothermal gradient over the area was accomplished by utilising one dimensional heat conductive model. The model, which depends on Fourier's law (Kasidi and Nur, 2012), is based on the following mathematically expressions.

$$
q=k \frac{d T}{d z}
$$

Where:

$q=$ Quantity of heat flow

$k=$ Coefficient of thermal conductivity

$\frac{d T}{d z}=$ Thermal gradient which is presumable constant as no heat gain or loss above the crust and below the Curie point depth

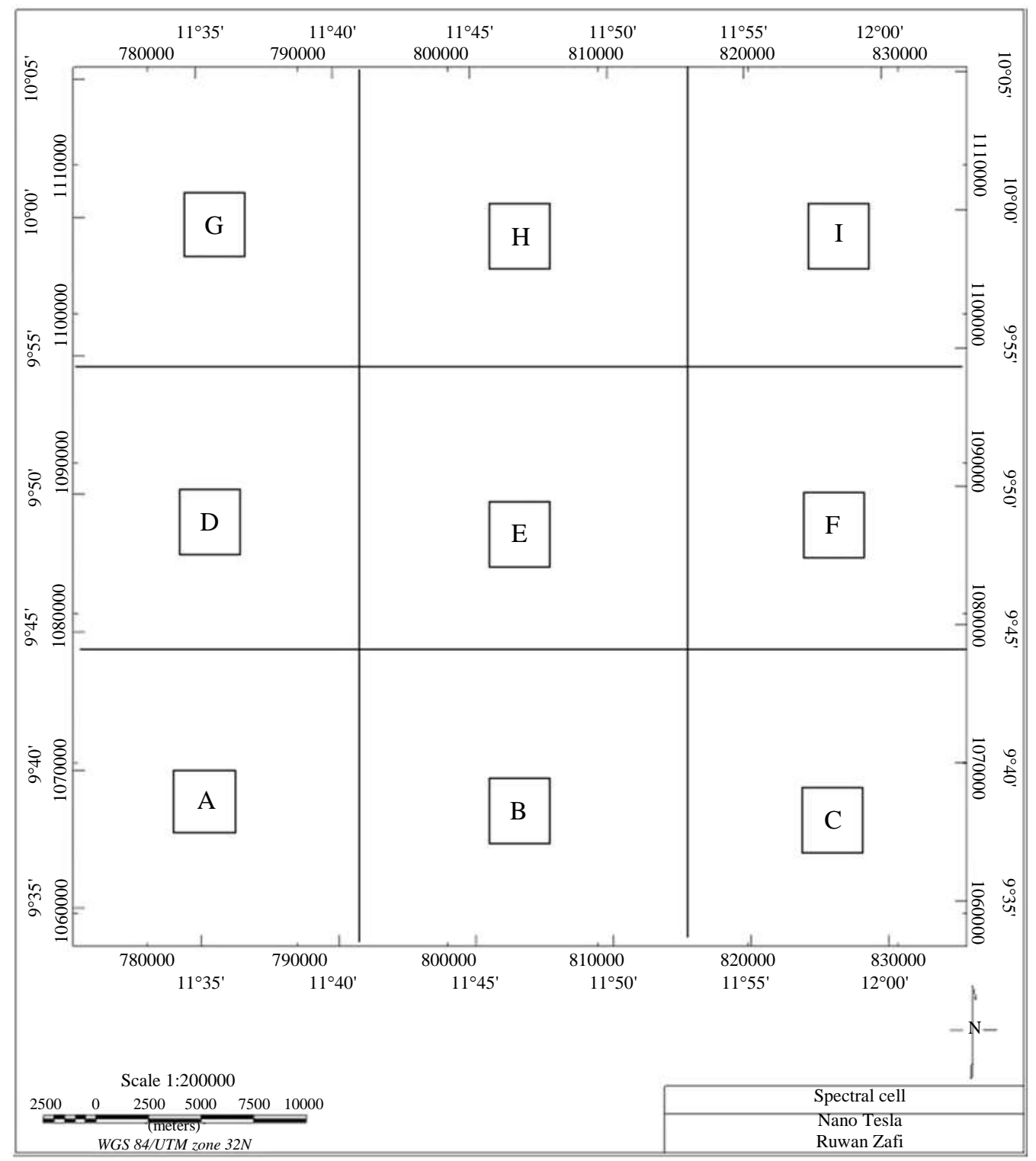

Fig. 2: Spectral cell blocks spectral analysis 
The Curie temperature $(\theta)$ is defined (Nwankwo and Ekine, 2010) as:

$\theta=\left(\frac{d T}{d z}\right) z_{b}$

Equation 2 and 3, we have:

$q=\left(k \frac{\theta}{z_{b}}\right)$

This research work used Equation 4 to deduce the heat flow within the area under study after the basal depths were calculated. For this deduction to be possible, (Nwankwo et al., 2011) suggested $580^{\circ} \mathrm{C}$ and 2.5 $\mathrm{Wm}^{-1}{ }^{\circ} \mathrm{C}^{-1}$ as standards or constants for Curie point isotherm and thermal conductivity respectively. However, $550^{\circ} \mathrm{C}$ was used in the calculation instead of the value $\left(580^{\circ} \mathrm{C}\right)$ suggested by (Nwankwo et al., 2011), because the temperature under study corresponds to the exploitable temperature at depth. That is, the surface temperature (noise) of $30^{\circ} \mathrm{C}$ was subtracted from $580^{\circ} \mathrm{C}$ in order to account for the temperature resulting from the subsurface.

Equation 3 was utilised in the estimation of the geothermal gradient, hence:

$\frac{d T}{d z}=\frac{\theta}{z_{b}}$

Where:

$\frac{d T}{d z}=$ Geothermal gradient

$z b=$ The basal depth

$\theta=$ The standard temperature of $550^{\circ} \mathrm{C}$

\section{Results}

The intensity of the total magnetic field map of the area under study is presented in Figure 3 and it shows the effects of the underlying basement, as well as the effects of near surface structures within the area. The Total Magnetic Intensity (TMI) map also shows that the area is characterised by high, intermediate and low amplitude magnetic anomalies with intensities ranging from 32935.2 to $>33049.1 \mathrm{nT}$. Places in the central part of the area, that is, within Guyuk and Banjiram, are characterised by short wavelength (high frequency) anomalous bodies, with high and low magnetic amplitudes and predominantly have NE-SW and NW-SE trends and with minor E-W trend. The eastern part of the area is predominantly characterised by anomalous bodies with both low frequency (long wavelength) and high frequency (short wavelength). The short wavelength is observed more within Kiri; it is also characterised by low to moderate magnetic amplitudes. The southeastern part of the area, within Ngbalang, is predominantly characterised by both long wavelength (low frequency) and short wavelength (high frequency) anomalous bodies that have high magnetic amplitudes; the bodies also appear to predominantly have N-S and NW-SE trends. Southwestern part of the area, within Bambam, is predominantly characterised by both long and short wavelength anomalous bodies with low magnetic amplitudes; while Lamurde Area is characterised by moderate magnetic amplitudes. The northern part of the study area, within Goratoro, Mada, Kombo and Galengu, is characterised by low magnetic amplitudes. The TMI map shows the presence of six fault zones (F1-F6) and the actual location of these linear structures are illustrated on the map presented in Fig. 4. The residual magnetic intensity map of the area is presented in Fig. 5 and the figure was utilized to delineate near surface structures/units within the area. Notable structures were labelled S1 to S5.

\section{Curie Depth, Geothermal Gradient and Heat Flow in the Study Area}

The spectral analysis of the dataset of the magnetic anomaly over the area under study produced the results presented in Fig. 6(a-i). Sediment thickness, that is, centroid depth $\left(Z_{0}\right)$ and top boundary depth or the shallowest depth to magnetic sources $\left(Z_{t}\right)$, within the area, were deduced from the spectral plots and the results were presented in Table 1. Curie depth, by definition, is the depth in the crust at which magnetism is lost. Centered on this definition, the Curie isotherm depths were computed using the depths of the shallowest $\left(Z_{t}\right)$ and deepest $\left(Z_{0}\right)$ sources which were deduced by employing the spectral analysis method (Bhattacharyya and Leu, 1975) and the results were presented in Table 1. The depths to centroid range from 4273.583 to $8693.315 \mathrm{~m}$ and the depths to the top of the magnetic bodies, within the area, range from 89.619 to $235.381 \mathrm{~m}$. Variation in Curie isotherm depths, within the area, is displayed in the map presented in Fig. 7 and the result shows a range from 8.40 to $17.16 \mathrm{~km}$. The deeper Curie depths range from about 12.05 to $17.16 \mathrm{~km}$ within the study area.

Using a temperature of $550^{\circ} \mathrm{C}$, the variations in geothermal gradient, within the area, were computed; the map showing the variation is presented in Fig. 8. Thermal conductivity of $2.5 \mathrm{Wm}^{-1}{ }^{\circ} \mathrm{C}^{-1}$, suggested by (Nwankwo et al., 2009) and the computed geothermal gradients were utilised in the calculation of the corresponding heat flow anomalies, within the place under study and the map is presented in Fig. 9. The results obtained show that the geothermal gradient variation deduced in this study varies between 33.79 
and $69.01^{\circ} \mathrm{C} / \mathrm{km}$, within the study area. Gradient range between 48.11 and $69.01^{\circ} \mathrm{C} / \mathrm{km}$ was delineated within Lamurde, Ruwan Zafi, Lafia, Kiri, Banjiran and Shellen Areas, while Bambam, Galengu and Ngbalang Areas have geothermal gradients less than $48.11^{\circ} \mathrm{C} / \mathrm{km}$. The corresponding mantle heat flow ranges from about 120.26 to $172.52 \mathrm{~mW} / \mathrm{m}^{2}$ within
Lamurde, Ruwan Zafi, Lafia, Kiri, Banjiran and Shellen and 84.48 to $<120.26 \mathrm{~mW} / \mathrm{m}^{2}$ within Bambam, Galengu and Ngbalang Areas.

The relationship between heat flow and basal (Curie) depths $\left(Z_{b}\right)$ within the study area was also investigated in this study. Figure 10 shows how the heat associated with the area at depth varies with Curie depth.

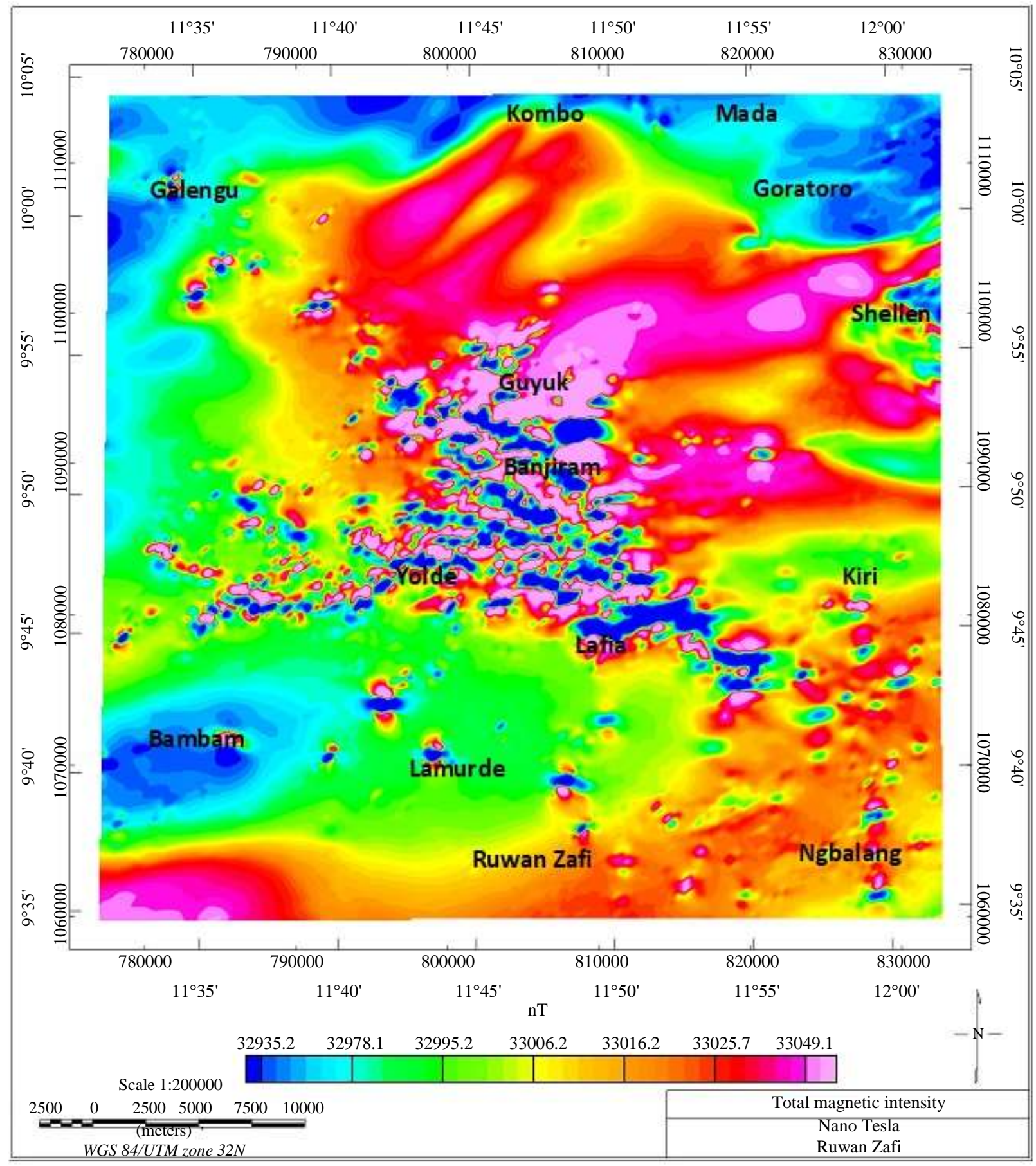

Fig. 3: Total Magnetic Intensity (TMI) map of the study area (nT) 
Ibe Stephen Onyejiuwaka and Uche Kelvin Iduma / Current Research in Geoscience 2020, Volume 10: 1.15 DOI: 10.3844/ajgsp.2020.1.15

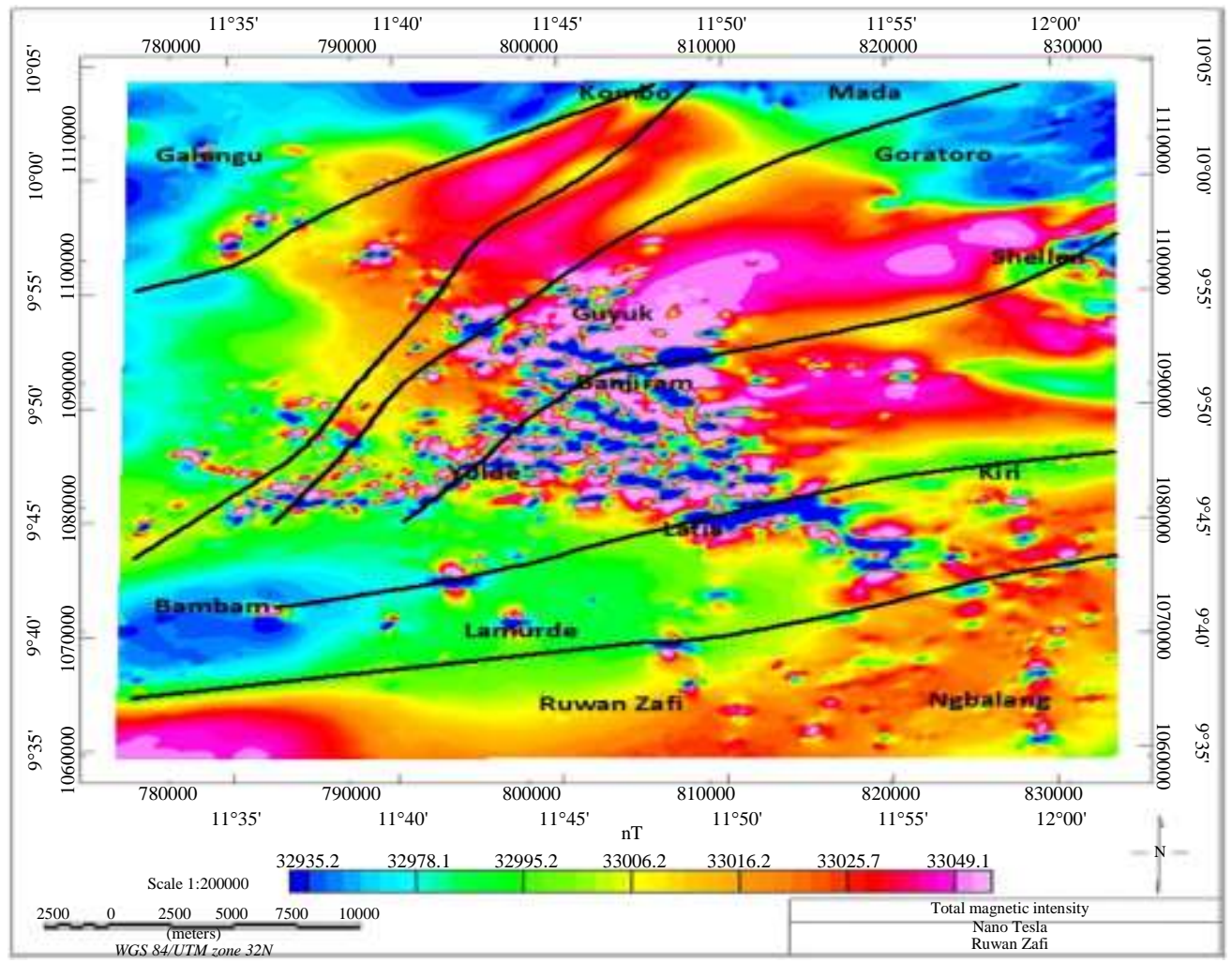

Fig. 4: Total Magnetic Intensity (TMI) map with interpreted faults (nT)

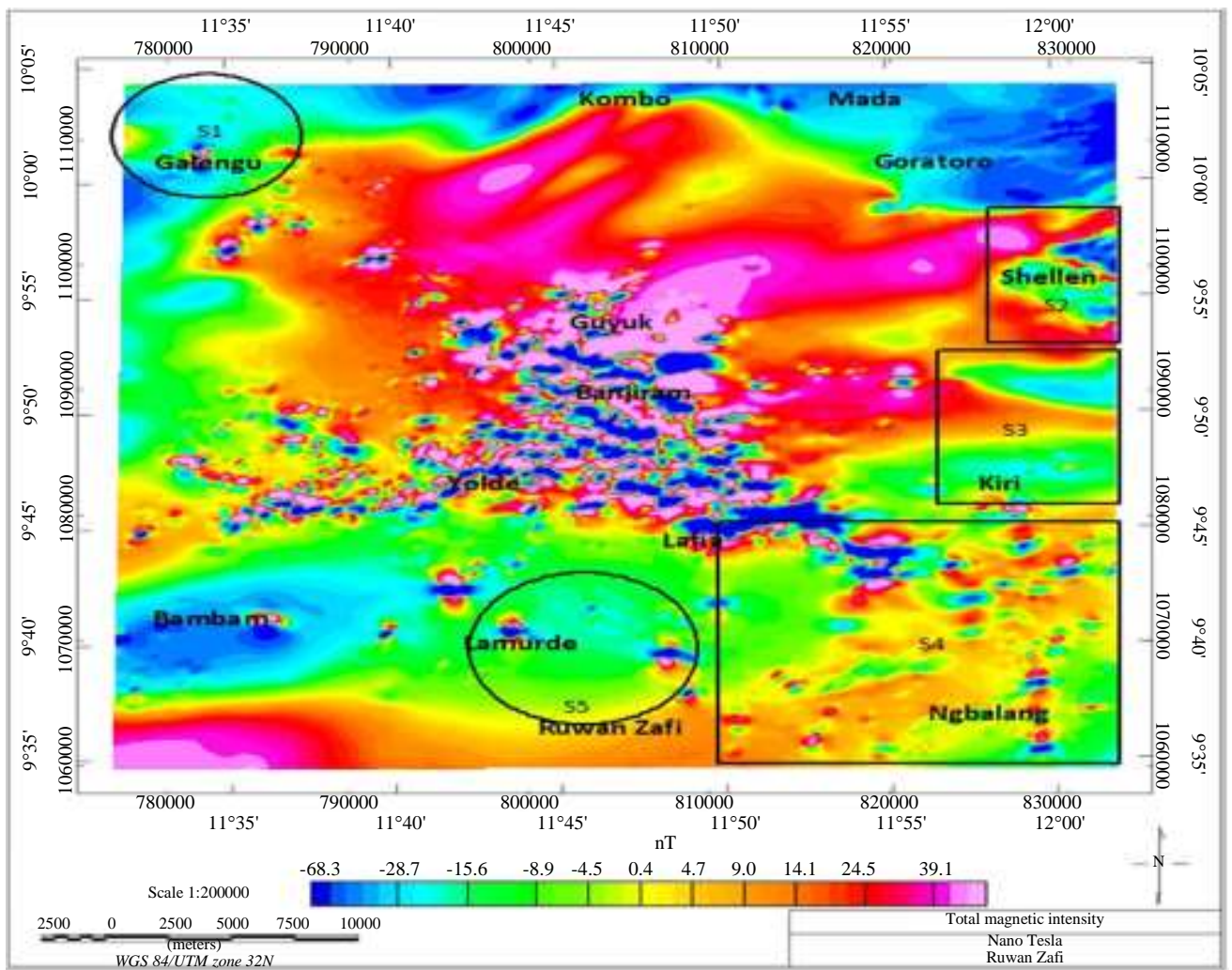

Fig. 5: Residual magnetic intensity map of the study area (nT) 
Ibe Stephen Onyejiuwaka and Uche Kelvin Iduma / Current Research in Geoscience 2020, Volume 10: 1.15 DOI: 10.3844/ajgsp.2020.1.15

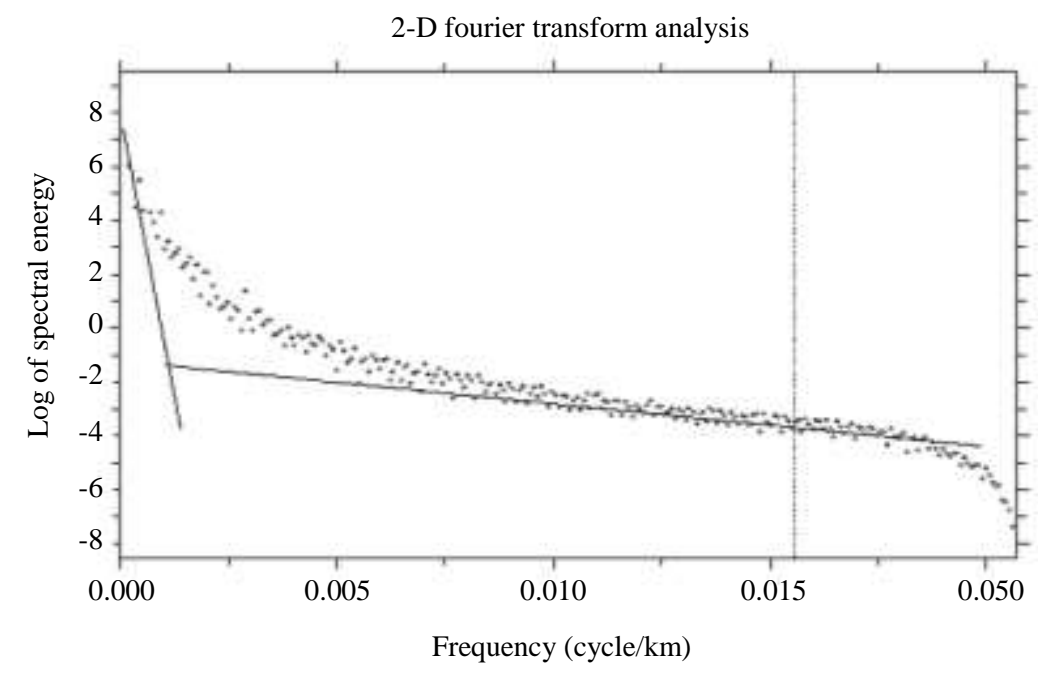

(a)

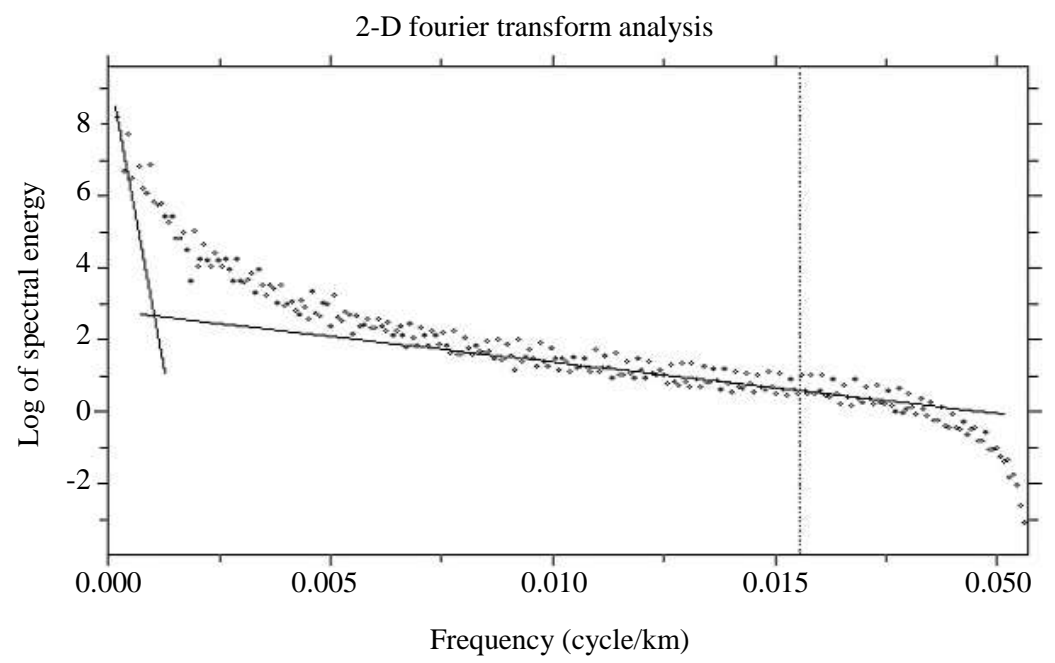

(b)

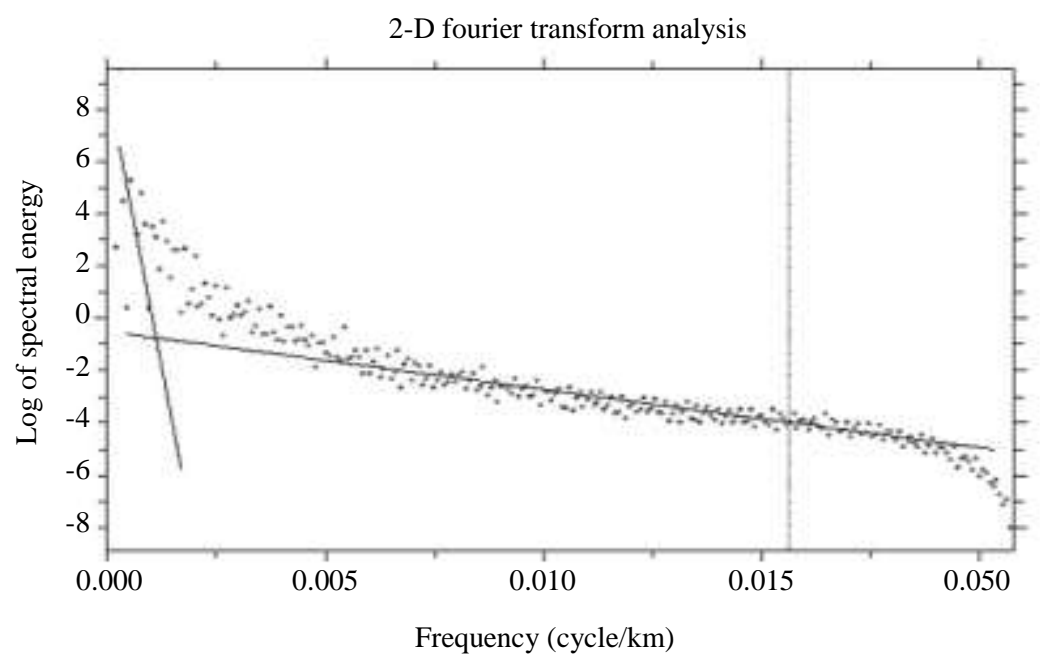

(c) 
Ibe Stephen Onyejiuwaka and Uche Kelvin Iduma / Current Research in Geoscience 2020, Volume 10: 1.15 DOI: 10.3844/ajgsp.2020.1.15

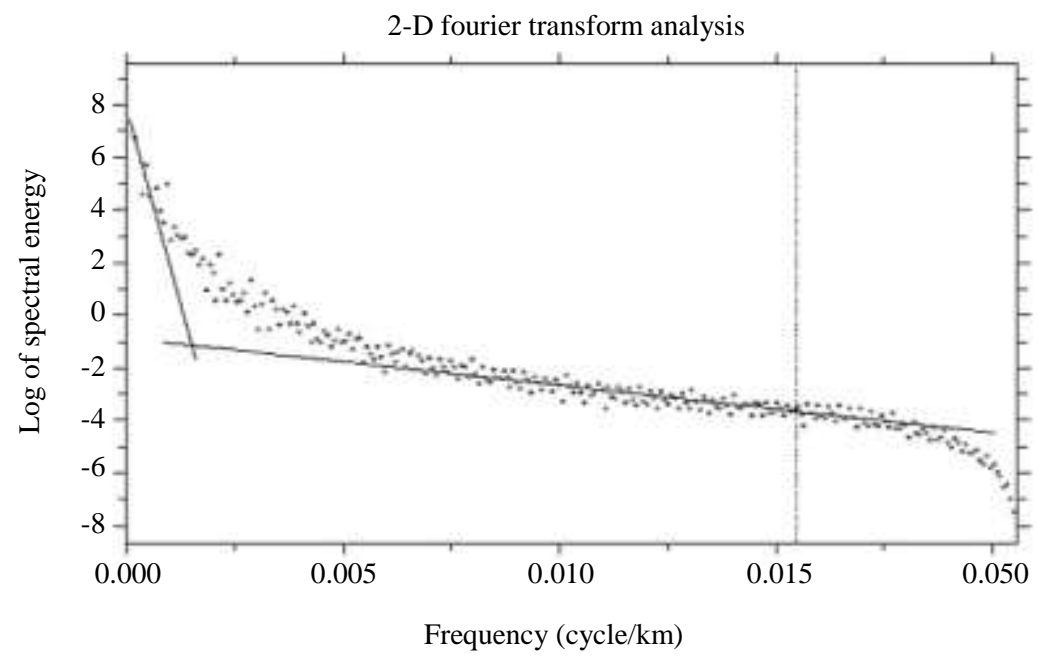

(d)

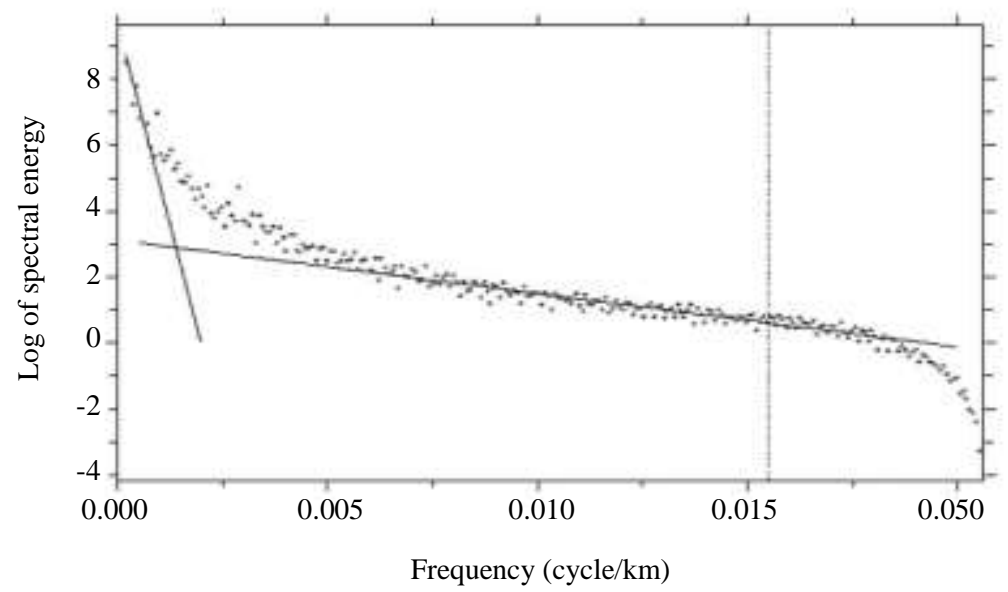

(e)

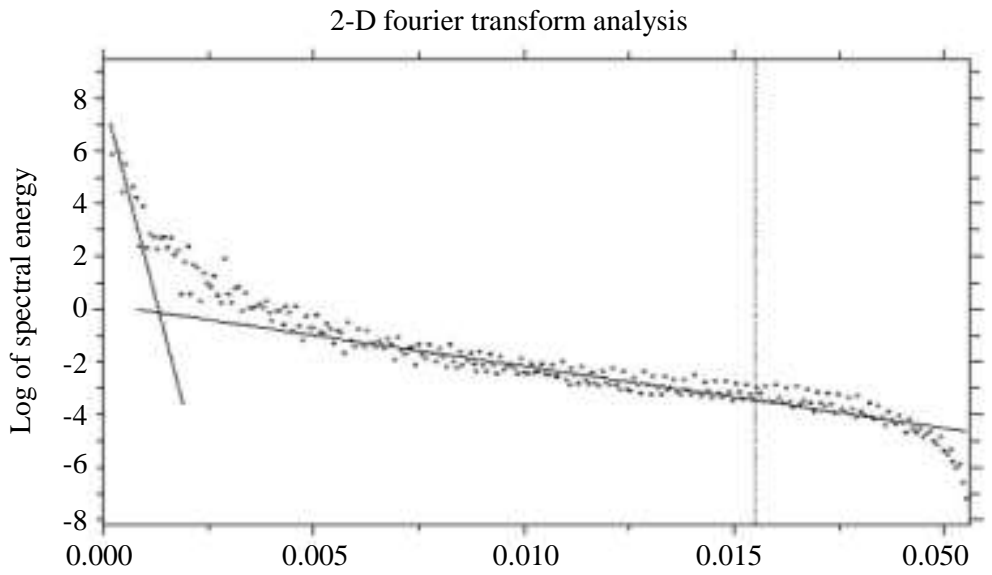

Frequency (cycle/km)

(f) 


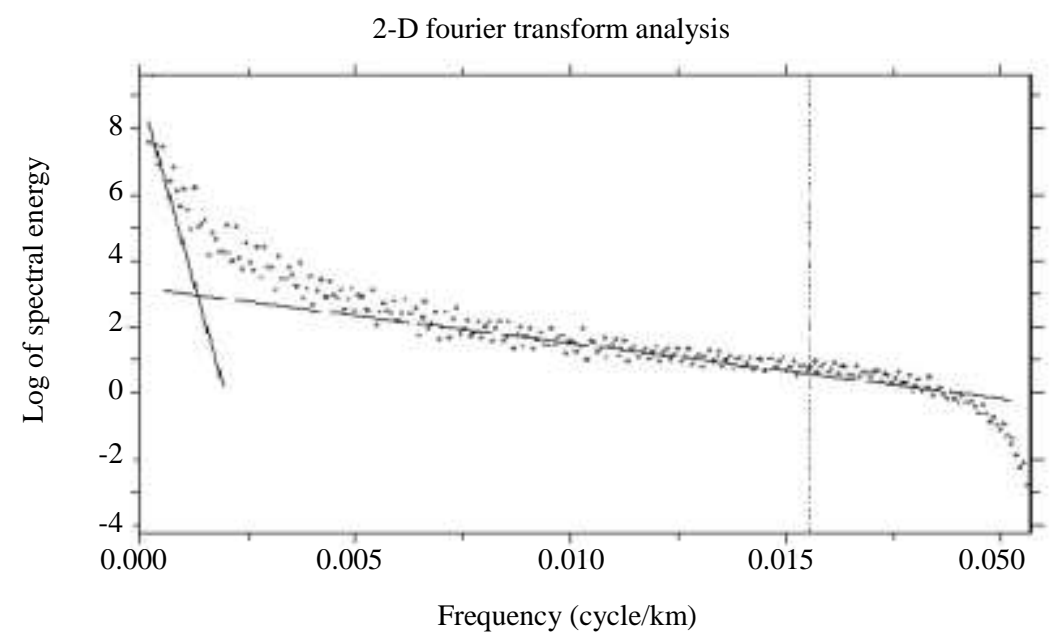

(g)

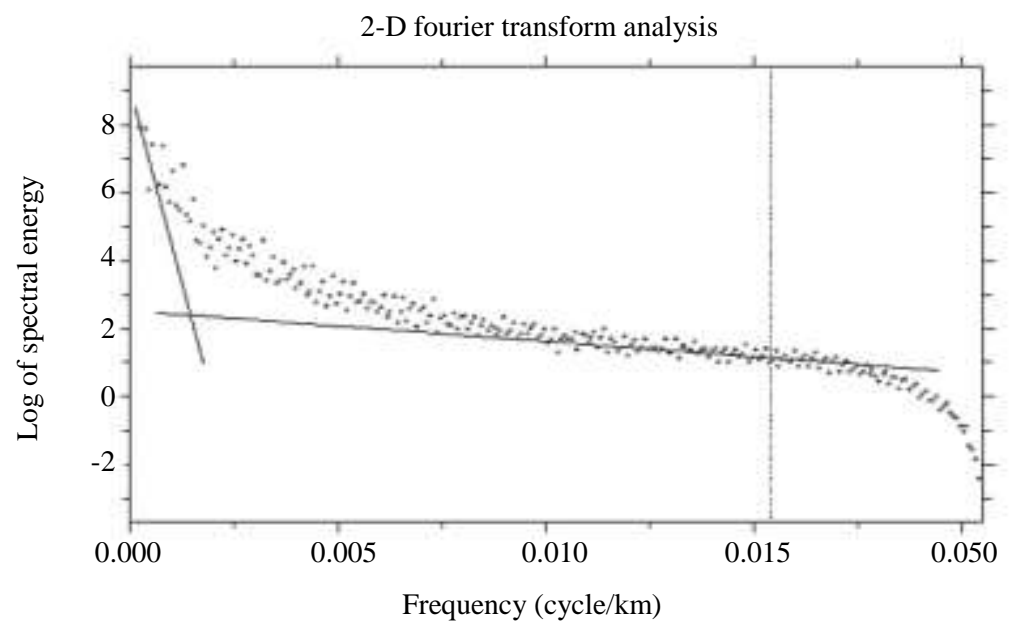

(h)

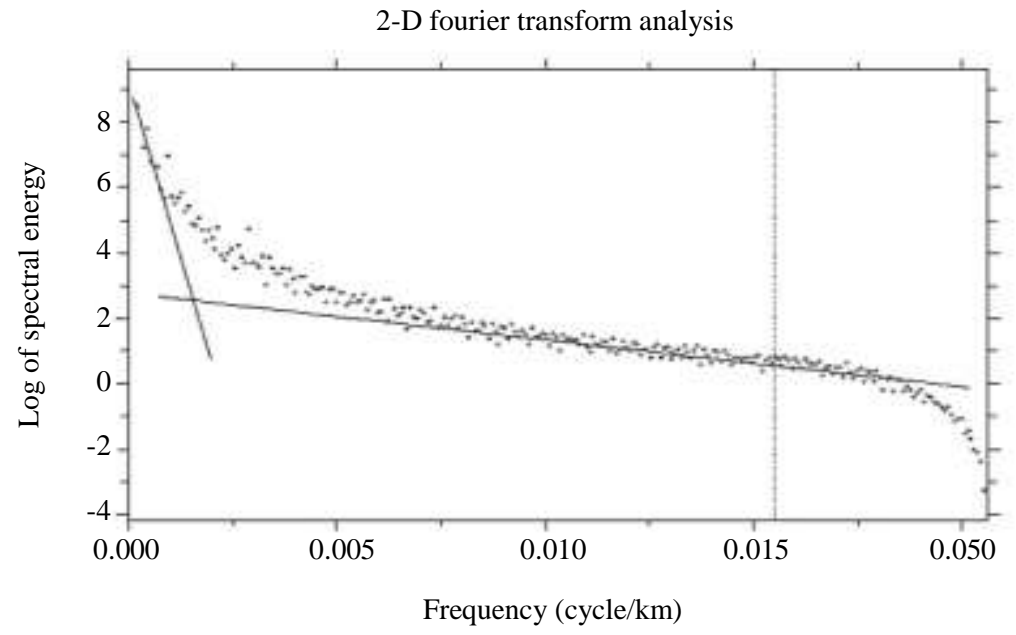

(i)

Fig. 6: (a) Spectral plot for cell A; (b) Spectral plot for cell B; (c) Spectral plot for cell C; (d) Spectral plot for cell D; (e) Spectral plot for cell E; (f) Spectral plot for cell F; (g) Spectral plot for cell G; (h) Spectral plot for cell H; (i) Spectral plot for cell I 
Ibe Stephen Onyejiuwaka and Uche Kelvin Iduma / Current Research in Geoscience 2020, Volume 10: 1.15 DOI: 10.3844/ajgsp.2020.1.15

\begin{tabular}{|c|c|c|c|c|c|c|}
\hline $\begin{array}{l}\text { Spectral } \\
\text { cell }\end{array}$ & $\begin{array}{l}\text { Centroid } \\
\text { depth } Z_{0}(\mathrm{~m})\end{array}$ & $\begin{array}{l}\text { Depth to top } \\
\text { boundary } Z_{t}(\mathrm{~m})\end{array}$ & $\begin{array}{l}\text { Curie Point } \\
\text { depth } Z_{b}(\mathrm{~m})\end{array}$ & $\begin{array}{l}\text { Curie point } \\
\text { depth } Z_{b}(\mathrm{~km})\end{array}$ & $\begin{array}{l}\text { Geothermal } \\
\text { gradient }\left({ }^{\circ} \mathrm{C} / \mathrm{Km}\right)\end{array}$ & $\begin{array}{l}\text { Heat flow } \\
q\left(\mathrm{~mW} / \mathrm{m}^{2}\right)\end{array}$ \\
\hline $\mathrm{A}$ & 8417.095 & 154.766 & 16679.42 & 16.67942 & 34.77338 & 86.93346 \\
\hline B & 4588.409 & 143.095 & 9033.723 & 9.033723 & 64.20387 & 160.5097 \\
\hline $\mathrm{C}$ & 8693.315 & 221.979 & 17164.65 & 17.16465 & 33.79038 & 84.47594 \\
\hline D & 7971.375 & 178.983 & 15763.77 & 15.76377 & 36.79324 & 91.98309 \\
\hline $\mathrm{E}$ & 4577.602 & 89.619 & 9065.585 & 9.065585 & 63.97822 & 159.9456 \\
\hline $\mathrm{F}$ & 4615.502 & 167.687 & 9063.317 & 9.063317 & 63.99423 & 159.9856 \\
\hline $\mathrm{G}$ & 6146.166 & 235.381 & 12056.95 & 12.05695 & 48.10503 & 120.2626 \\
\hline $\mathrm{H}$ & 7872.928 & 162.016 & 15583.84 & 15.58384 & 37.21804 & 93.0451 \\
\hline I & 4273.583 & 142.698 & 8404.468 & 8.404468 & 69.01091 & 172.5273 \\
\hline
\end{tabular}

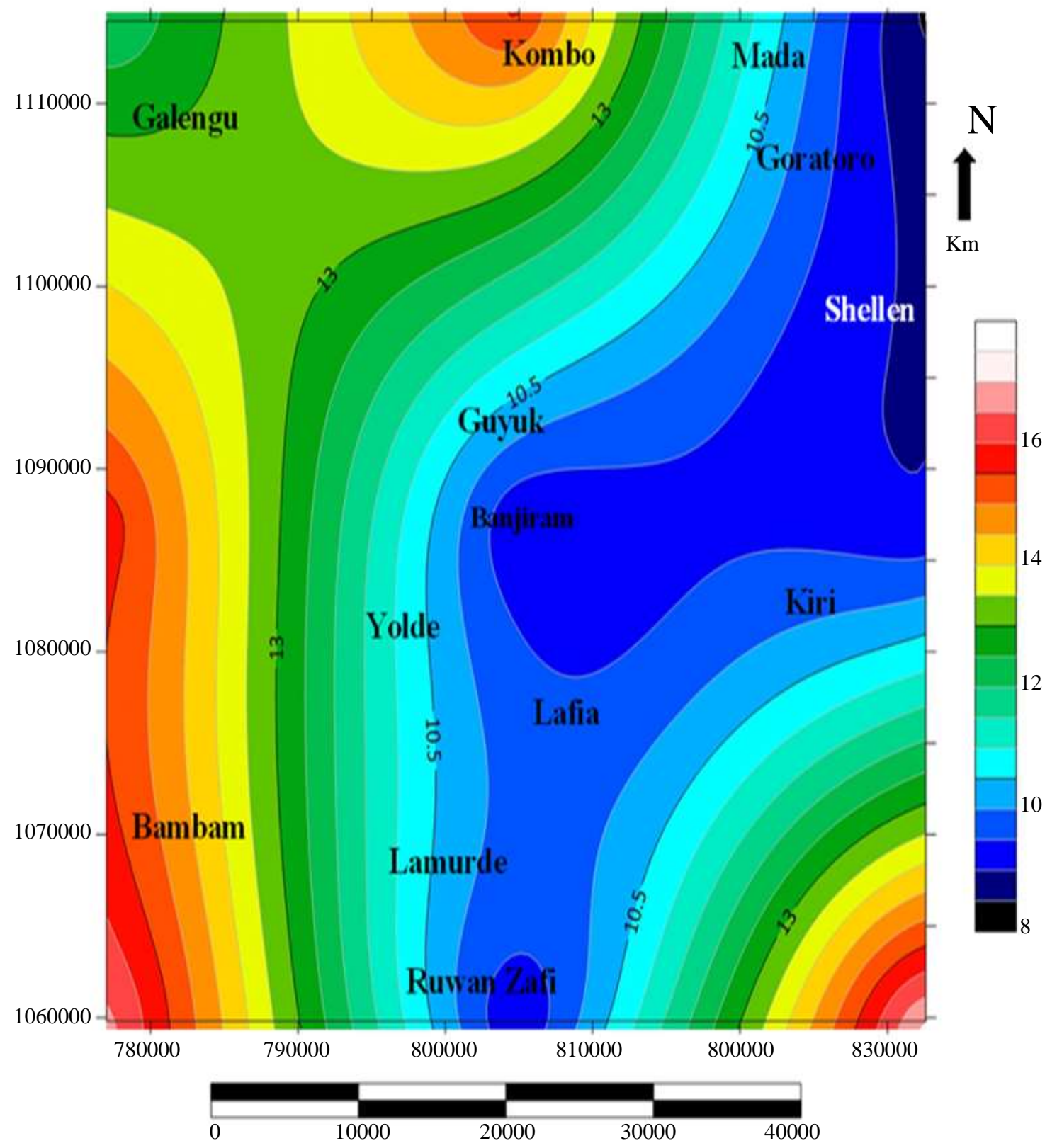

Fig. 7: Curie isotherm depth of the study area $(\mathrm{km})$ 


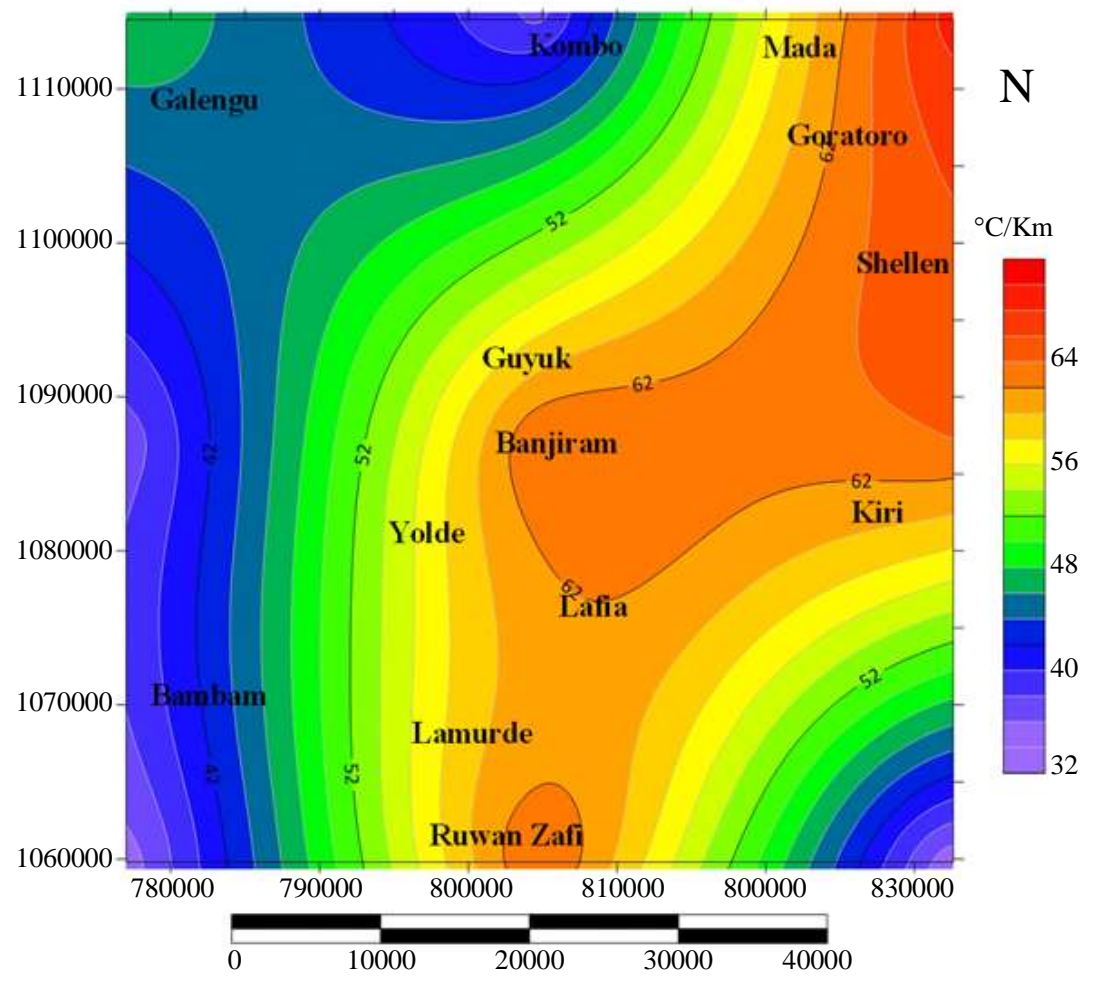

Fig. 8: Geothermal gradient map of the study area $\left({ }^{\circ} \mathrm{C} / \mathrm{km}\right)$

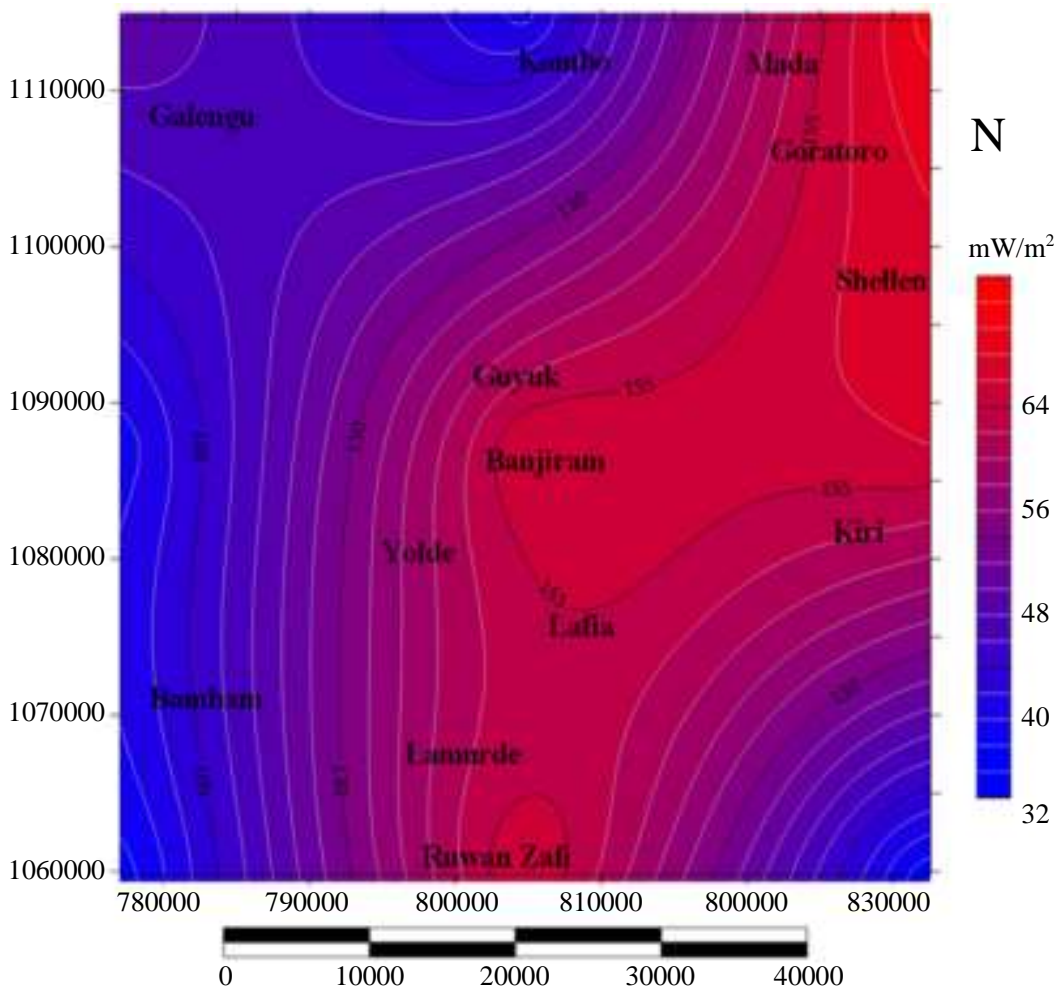

Fig. 9: Heat flow gradient map of the study area $\left(\mathrm{mW} / \mathrm{m}^{2}\right)$ 


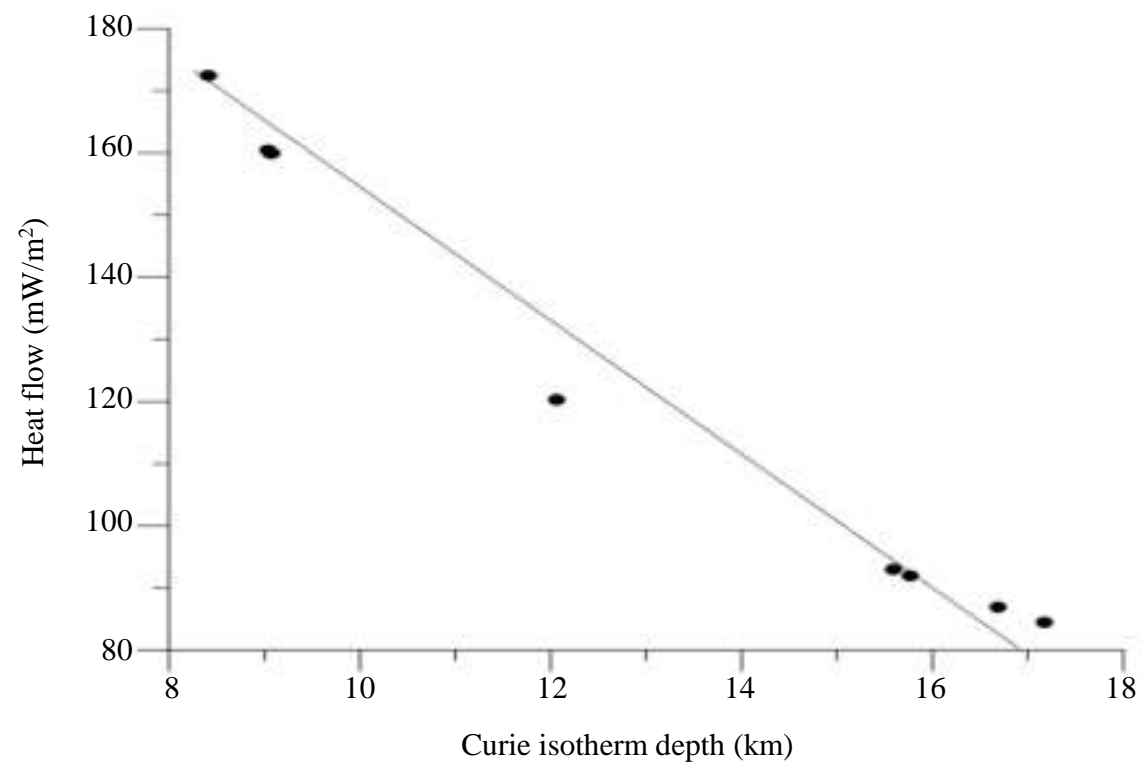

Fig. 10: Relationship between curie depth and heat flow within the study area

\section{Discussion}

The zones of low magnetic intensities (Fig. 3), within Goratoro, Mada, Kombo and Galengu Areas, are most likely due to the responses from deep seated magnetic sources, with thick sediments/sedimentary cover. Intermediate magnetic intensities are most likely due to highly consolidated ferruginized sediments or near surface magnetic sources. High magnetic intensities suggest responses from shallow or surface magnetic sources of possible basement rocks/intrusives. The high and low magnetic amplitudes observed at the central part (Banjiram, Guyuk and Yolde) and western side of the area, are due to bipolar nature of magnetic minerals. Hence, the area is interpreted to be highly deformed by intrusive rock units. The northern part of the area is hence, most likely a transitional area, from the Western Basement Complex of Nigeria, to the Central part of the Benue Trough, while the central part of the area, is most likely characterised by granitic and basaltic rocks of Nigeria's Western Basement Complex.

Qualitative interpretation of the total magnetic intensity mapped six major regional faults within the study area (Fig. 4). The faults trend majorly in the NESW direction. The major faults are defined as pre-basin fault systems, formed as a result of the break-up of the South American and African Continents during Early Cretaceous (Burke, 1976). These fault systems are in agreement with the various cases of Paleontologic, geomorphologic, structural and stratigraphic postulations tendered to support a rift model (Bullard et al., 1965; Guiraud and Bellion, 1995).

Low amplitude bodies were better enhanced and associated with the southern and eastern parts of the area (S2, S3 and S5) (Fig. 5). Low amplitude or depletion in magnetic susceptibility at the near surface is closely related to an increase in temperature, because increase in temperature yields a decrease in magnetism of a body. The areas are located within Lamurde, Ruwan Zafi and Kiri which are known to have geothermal springs (Bassi and Alfred, 2018).

Figure 7 shows that the shallowest Curie depths in this study were delineated within Lamurde, Ruwan Zafi, Lafia, Kiri, Banjiran and Shellen while the deeper Curie depths were delineated within Bambam, Galengu and Ngbalang. Figure 8 shows regions associated with high geothermal gradient at Lamurde, Ruwan Zafi, Lafia, Kiri, Banjiran and Shellen and low geothermal gradient at Bambam, Galengu and Ngbalang. Comparing Fig. 8 with Fig. 9 suggests that most places associated with high heat flow match almost exactly with high geothermal gradient. The variation of heat flow within the area indicates random distribution of magma conduits. The heat flow associated with the area, which is delineated in this study, compare favourably well with the results of other works on heat flow within the Inland Basins of Nigeria (Nur et al., 1999; Akpabio and Ejedawa, 2001; 2010; Nwankwo et al., 2009; Kasidi and Nur, 2012; 2013; Anakwuba and Chinwuko, 2015).

It can be deduced from this study that the geothermal vibrant places in the area under study are most likely in the regions where thin layer of thermally insulated sediments cover basement rocks and volcanic activities as delineated within Lamurde, Ruwan Zafi, Lafia, Kiri, Banjiran and Shellen Areas. The calculated geothermal gradient of the study area (average $50.2^{\circ} \mathrm{C} / \mathrm{km}$ ) is above the thermal gradient average of $23.56^{\circ} \mathrm{C} / \mathrm{km}$ measured from nineteen exploration wells within the Eastern Niger Delta Basin by (Emujakporue and Ekine, 2014). The geothermal gradient greater than $48.11^{\circ} \mathrm{C} / \mathrm{km}$ and heat 
flow greater than $120.26 \mathrm{~mW} / \mathrm{m}^{2}$ reflect high potential of the occurrence of geothermal resources within Lamurde, Ruwan Zafi, Lafia, Kiri, Banjiran and Shellen. This is in agreement with (Bassi and Alfred, 2018) which marked the occurrence of warm springs around Lamurde and Ruwan Zafi as great sites for tourist attraction.

This study showed a relationship that is almost inverse proportional between heat flow and basal (Curie) depths $\left(Z_{b}\right)$ (Fig. 10). This suggests that increase in Curie isotherm depth most likely causes a decrease in heat flow within the place.

Researches have shown that basal depth is usually associated with geological context. Basal depths are shallower than about $10 \mathrm{~km}$ at volcanic and geothermal areas, 15 to $25 \mathrm{~km}$ at island arcs and ridges, deeper than $20 \mathrm{~km}$ at plateaus and deeper than $30 \mathrm{~km}$ at trenches (Tanaka et al., 1999). The warm springs that characterise many locations within the area under study, favourably qualify the places for the first description. Bassi and Alfred (2018) had stated that the warm springs within the area issue with temperatures above $50^{\circ} \mathrm{C}$.

Estimated basal depths delineated from sub-regions centered over Lamurde and Ruwan Zafi Areas (known for the occurrences of warm springs) are predominantly shallower than those associated with places (Bambam, Galengu and Ngbalang) farther from them. Shallow Curie point depth values were also delineated in some places farther from the known warm spring region within the Lafia, Kiri, Banjiran and Shellen. The shallow Curie depths observed in these areas, most likely, could be due to the intruded Older Granite unit, marked by the occurrence of bipolar structures, underlying central and southern regions in the study area. This peculiar observation led to the suggestion that the shallow basal depth, coupled with high heat flow, within Lamurde, Ruwan Zafi, Lafia, Kiri, Banjiran and Shellen, most likely, could also be on account of magmatic intrusion at depth in the vastly fractured basement rocks. The Nigeria Basement Complex was in places intruded and interspersed by Older Granites which had originated during the PanAfrican Orogeny (Oluyide and Udoh, 1989). A thick magnetic crust suggests stable continental regions, while thin magnetic crust accounts for tectonically active regions, also associated with higher heat flow (Rajaram et al., 2009). This interpretation has reveals that Lamurde, Ruwan Zafi, Lafia, Kiri, Banjiran and Shellen are areas of hot prospect of geothermal resources.

\section{Conclusion}

The geothermal gradient, above $48.11^{\circ} \mathrm{C} / \mathrm{km}$ and heat flow, greater than $120.26 \mathrm{~mW} / \mathrm{m}^{2}$, delineated within Lamurde, Ruwan Zafi, Lafia, Kiri, Banjiran and Shellen regions of the area imply high potentials of the occurrences of geothermal resources at the places. Also, these places have the shallowest depths to magnetic sources and thermal gradients above the conversional crustal gradient and are the areas of highest prospects of geothermal resources, within the study area. It is expected that if the geothermal energy in these places is harnessed in electricity generation in Nigeria, the poor industrial growth resulting from poor electric power generation and supply will be ameliorated significantly.

\section{Acknowledgement}

The authors are sincerely grateful to the Nigerian Geological Survey Agency (NGSA) for providing the data used for this study.

\section{Author's Contributions}

Ibe Stephen Onyejiuwaka: Carried out literature review, processed the data, presented and discussed the results.

Uche Iduma: Assisted in processing the data, read and edited the manuscript.

\section{Ethics}

This article is original and contains unpublished material. The corresponding author confirms that all of the other authors have read and approved the manuscript and no ethical issues involved.

\section{Reference}

Abubakar, M. B., Obaje, N. G., Luterbacher, H. P., Dike, E. F. C., \& Ashraf, A. R. (2006). A report on the occurrence of Albian-Cenomanian elater-bearing pollen in Nasara-1 well, Upper Benue Trough, Nigeria: Biostratigraphic and palaeoclimatological implications. Journal of African Earth Sciences, 45(3), 347-354.

Akpabio, I. O., \& Ejedawe, J. E. (2001). Mathematics, Physics and Computer Sciences Temperature variations in the Niger Delta subsurface from continuous temperature logs. Global Journal of Pure and Applied Sciences, 7(1), 137-142.

Akpabio, I., \& Ejedawe, J. (2010). Thermal conductivity estimates in the Niger Delta using lithologic data and geophysical well logs. Current Science, 411-417.

Akuru, U. B., \& Okoro, O. I. (2014). Renewable energy investment in Nigeria: A review of the Renewable Energy Master Plan. Journal of Energy in Southern Africa, 25(3), 62-67.

Anakwuba, E. K., \& Chinwuko, A. I. (2015). One dimensional spectral analysis and Curie depth isotherm of Eastern Chad Basin, Nigeria. Journal of Natural Sciences Research, Vol5 No19, 14-22.

Bassi, P., \& Alfred, D. M. (2018). Spatial distribution of tourist attraction sites in Southern Geo-political zone of Adamawa State, Nigeria. Intern. J. Innov. Educ. Res. 6, 91-98. 
Bhattacharyya, B. K., \& Leu, L. K. (1975). Spectral analysis of gravity and magnetic anomalies due to two-dimensional structures. Geophysics, 40(6), 993-1013.

Blakely, R. J. (1988). Curie temperature isotherm analysis and tectonic implications of aeromagnetic data from Nevada. Journal of Geophysical Research: Solid Earth, 93(B10), 11817-11832.

Bullard, E., Everett, J. E., \& Gilbert Smith, A. (1965). The fit of the continents around the Atlantic. Philosophical Transactions of the Royal Society of London. Series A, Mathematical and Physical Sciences, 258(1088), 41-51.

Burke, K. (1976). Development of graben associated with the initial ruptures of the Atlantic Ocean. In Developments in Geotectonics (Vol. 12, pp. 93112). Elsevier.

Charles, O. C., \& Omokenu, E. G. (2018). Curie Point Depth (CPD) Investigation Of Offshore Niger Delta Using High Resolution Aeromagnetic Data. American Journal of Geoscience, 8(1), 14-26.

Emujakporue, G. O., \& Ekine, A. S. (2014). Determination of geothermal gradient in the Eastern Niger Delta Sedimentary Basin from bottom hole temperatures. J. of Earth Sc. \& Geotech. Eng, 4(3), 109-114.

Guiraud, M. (1990). Tectono-sedimentary framework of the early Cretaceous continental Bima formation (upper Benue Trough, NE Nigeria). Journal of African Earth Sciences (and the Middle East), 10(1-2), 341-353.

Guiraud, R., \& Bellion, Y. (1995). Late Carboniferous to Recent, Geodynamic evolution of the west Gondwanian, cratonic, Tethyan margins. In The Tethys Ocean (pp. 101-124). Springer, Boston, MA.

Hisarli, Z. M. (1996). Determination of Curie Point Depths in Western Anatolia and Related with the Geothermal Areas. Ph. D. Thesis, Istanbul University.

Kasidi, S., \& Nur, A. (2012). Curie depth isotherm deduced from spectral analysis of Magnetic data over Sarti and environs of North-Eastern Nigeria. Sch J Biotech, 1, 49-56.

Kasidi, S., \& Nur, A. (2013). Estimation of Curie Point Depth, Heat flow and Geothermal Gradient Inferred from Aeromagnetic Data over Jalingo and Environs North-Eastern Nigeria. International Journal of Earth Science and Engineering, 6(6), 294-301.

Pirttijärvi, M. (2014). FOURPOT Potential field data processing and analysis of using 2-D Fourier transform. User's guide to version, 1.

Mayhew, M. A. (1985). Curie isotherm surfaces inferred from high-altitude magnetic anomaly data. Journal of Geophysical Research: Solid Earth, 90(B3), 2647-2654.
Newsom, C. (2012). Renewable Energy Potential in Nigeria: Low-carbon approaches to tackling Nigeria's energy poverty. International Institute for Environment and Development, 2012, 21.

Nur, A. O. C. O. K., Ofoegbu, C. O., \& Onuoha, K. M. (1999). Estimation of the depth of the Curie Point isotherm in the Upper Benue trough, Nigeria. Journal of Mining and Geology, 35(1), 53-60.

Dolmaz, M. N., Ustaömer, T., Hisarli, Z. M., \& Orbay, N. (2005). Curie point depth variations to infer thermal structure of the crust at the African-Eurasian convergence zone, SW Turkey. Earth, planets and space, 57(5), 373-383.

Nwankwo, C., \& Ekine, A. (2010). Geothermal gradients in the Chad Basin, Nigeria, from bottom hole temperature logs. International Journal of physical sciences, 4(12), 777-783.

Nwankwo, N. C., Anthony, A. S., \& Nwosu, L. I. (2009). Estimation of the heat flow variation in the Chad Basin Nigeria. Journal of Applied Sciences and Environmental Management, 13(1).

Nwankwo, L. I., Olasehinde, P. I., \& Akoshile, C. O. (2011). Heat flow anomalies from the spectral analysis of airborne magnetic data of Nupe Basin, Nigeria. Asian Journal of Earth Sciences, 4(1), 20.

Okubo, Y., \& Matsunaga, T. (1994). Curie point depth in northeast Japan and its correlation with regional thermal structure and seismicity. Journal of Geophysical Research: Solid Earth, 99(B11), 22363-22371.

Oluyide, P. O., \& Udoh, A. N. (1989). Preliminary comments on the fracture systems of Nigeria. In National seminar on earthquakes in Nigeria. 1 (pp. 97-109).

Rajaram, M., Anand, S. P., Hemant, K., \& Purucker, M. E. (2009). Curie isotherm map of Indian subcontinent from satellite and aeromagnetic data. Earth and Planetary Science Letters, 281(3-4), 147-158.

Stampolidis, A., \& Tsokas, G. N. (2002). Curie point depths of Macedonia and Thrace, N. Greece. Pure and Applied Geophysics, 159(11-12), 2659-2671.

Tanaka, A., Okubo, Y., \& Matsubayashi, O. (1999). Curie point depth based on spectrum analysis of the magnetic anomaly data in East and Southeast Asia. Tectonophysics, 306(3-4), 461-470.

Tselentis, G. A. (1991). An attempt to define Curie point depths in Greece from aeromagnetic and heat flow data. pure and applied geophysics, 136(1), 87-101.

Tsokas, G. N., Hansen, R. O., \& Fytikas, M. (1998). Curie point depth of the island of Crete (Greece). Pure and Applied Geophysics, 152(4), 747-757.

USEIA. (2019). Electric Power Monthly. United States Energy Information Administration. https://www.eia.gov/electricity/monthly 